\title{
Anticoagulant Therapy in Moderate to Severe COVID-19 Patients
}

\author{
Agus Fitriyanto Achmad ${ }^{1 *}$, Yuni Iswati Raharjani ${ }^{2}$, Zidni Setyaningrum ${ }^{3}$, Bagus Andi \\ Pramono $^{4}$, Dita Ria Selvyana ${ }^{5}$, Sri Pramesthi Wisnu Bowo Negoro ${ }^{6}$ \\ ${ }^{1}$ Haematologist and Medical Oncologist, Internal Medicine Department of Panembahan Senopati Hospital, Bantul, \\ Yogyakarta, Indonesia \\ 2Pulmonologist, Internal Medicine Department of Panembahan Senopati Hospital, Bantul, Yogyakarta, Indonesia \\ ${ }_{3}^{3}$ Internist, Internal Medicine Department of Panembahan Senopati Hospital, Bantul, Yogyakarta, Indonesia \\ ${ }^{4}$ Cardiologist, Internal Medicine Department of Panembahan Senopati Hospital, Bantul, Yogyakarta, Indonesia \\ ${ }^{5}$ Internist, Internal Medicine Department of Medical Faculty of Universitas Muhammadiyah Yogyakarta, Bantul, \\ Yogyakarta, Indonesia \\ ${ }^{6}$ General Practitioner, Emergency Department of 'Aisyiyah Hospital, Nganjuk, East Java, Indonesia
}

DATE OF ARTICLE:

Received: 06 Nov 2021

Reviewed: 20 Dec 2021

Revised: 02 Jan 2022

Accepted: 18 Jan 2022

CORRESPONDENCE:

agusfachmad@yahoo.com

DOI:

10.18196/mmjkk.v21i2.11634

TYPE OF ARTICLE:

Case Report

\begin{abstract}
Coronavirus disease-19 (COVID-19) has a spectrum of severity from no symptoms to serious complications. Coagulopathy is a serious complication of COVID-19, and that condition is a marker of poor prognosis. Anticoagulant drugs are often used as prophylaxis and thrombosis therapy to treat COVID-19 patients. Anticoagulant therapy is indicated for moderate-severe COVID-19 patients. Low molecular weight heparin (LMWH) and Unfractionated Heparin (UFH) are anticoagulant drugs of choice for prophylaxis and thrombosis therapy in COVID-19 patients. When administering anticoagulant drugs, monitoring bleeding, renal function, and platelet count needs to be done, even if only as thromboprophylaxis. LMWH and UFH have good clinical efficacy with minimal side effects in managing COVID-19 patients.
\end{abstract}

Keywords: Anticoagulant; Coagulopathy; COVID-19; Low-Molecular-Weight Heparin; Unfractionated Heparin

\section{INTRODUCTION}

COVID-19 (coronavirus disease 19) is caused by the new coronavirus known as SARS-CoV-2 (severe acute respiratory syndrome coronavirus 2). Currently, COVID-19 is a worldwide pandemic that emerged at the end of 2019. ${ }^{1}$ The disease has a spectrum of severity from no symptoms, mild, moderate, severe with multiorgan failure conditions to mortality. ${ }^{2,3}$

Coagulopathy is a form of thromboembolism of the veins or arteries, a serious complication of COVID-19. This coagulopathy is a marker of poor prognosis in COVID-19 patients. ${ }^{4,5}$ There have been many reports regarding the incidence of thrombosis in COVID-19, the use of anticoagulant drugs as prophylaxis and thrombosis therapy, and the pathophysiology of thrombosis in COVID-19. ${ }^{6,7}$

This case report reports a series of anticoagulant therapy in moderate to severe COVID-19 patients with different comorbidities, including diabetes mellitus, hypertension, coronary heart disease, chronic heart failure, diabetic ketoacidosis, acute kidney failure injury, and chronic kidney disease. This report can be considered in administering anticoagulants to COVID-19 patients regarding indications, dosage, side effects, and clinical efficacy in the clinical setting of treatment for COVID-19 patients.

\section{CASES}

\section{CASE 1}

Mrs. A was 62 years old, with complaints of cough, shortness of breath, and fever for 5 days. She had comorbidities of hypertension, diabetes mellitus, and coronary heart disease. The patient was confirmed 
COVID-19 from a positive RT-PCR nasopharyngeal swab with chest X-ray bronchopneumonia. Mrs. A had moderate clinical symptoms with the d-dimer result of $1.08 \mu \mathrm{g} / \mathrm{dl}, 3.6$ times normal value $(0.3 \mu \mathrm{g} / \mathrm{dl})$. The patient was given enoxaparin (low molecular weight heparin / LMWH) $0.4 \mathrm{ml}$ per 24 hours with a d-dimer evaluation result of $0.91 \mu \mathrm{g} / \mathrm{dl}$ (day 3 of LMWH), $0.63 \mu \mathrm{g} / \mathrm{dl}$ (day 4 of LMWH), $0.61 \mu \mathrm{g} / \mathrm{dl}$ (day of $6 \mathrm{LMWH}$ ), $0.38 \mu \mathrm{g} / \mathrm{dl}$ (day 9 of $\mathrm{LMWH}$ ), then stopped LMWH therapy. There was no bleeding during LMWH administration, even in combination with aspilet. The patient went home with clinical and radiological improvement and a negative swab evaluation.

Table 1. Case-1 d-dimer Progression After Using Enoxaparin

\begin{tabular}{|c|c|c|c|c|c|}
\hline & \multicolumn{5}{|c|}{ Day of Enoxaparin Use } \\
\hline & Day-1 & Day-3 & Day-4 & Day-6 & Day-9 \\
\hline D-dimer $(\mu \mathrm{g} / \mathrm{dl})$ & 1.08 & 0.91 & 0.63 & 0.61 & 0.38 \\
\hline Dosage & $0.4 \mathrm{ml} / 24 \mathrm{~h}$ & $0.4 \mathrm{ml} / 24 \mathrm{~h}$ & $0.4 \mathrm{ml} / 24 \mathrm{~h}$ & $0.4 \mathrm{ml} / 24 \mathrm{~h}$ & Stop \\
\hline
\end{tabular}

\section{CASE 2}

Mr. B was 35 years old, complaining of shortness of breath for 3 days preceded by cough and fever. There was no previous history of other diseases. Mr. B confirmed COVID-19 from a positive RT-PCR nasopharyngeal swab with chest $X$-ray bilateral pneumonia, especially the right side. The clinical symptoms were moderate severity with a d-dimer result of $1.29 \mu \mathrm{g} / \mathrm{dl}$ ( 4.3 times the normal value). The patient was given enoxaparin $0.4 \mathrm{ml}$ per 24 hours. The evaluation result of d-dimer was $2.16 \mu \mathrm{g} / \mathrm{dl}$ (day 3 of LMWH), then the dose was increased to $0.4 \mathrm{ml}$ per 12 hours. The evaluation result of d-dimer was $0.86 \mu \mathrm{g} / \mathrm{dl}$ (day 5 of LMWH), then reduced the dose to $0.4 \mathrm{ml}$ per 24 hours. Evaluation result d-dimer on day 7 was $\mathrm{LMWH} 0.3 \mu \mathrm{g} / \mathrm{dl}$, and he then stopped. The clinical and radiological evaluation results finally improved.

Table 2. Case-2 d-dimer Progression After Using Enoxaparin

\begin{tabular}{lcccc}
\hline & \multicolumn{4}{c}{ Day of Enoxaparin Use } \\
& Day-1 & Day-3 & Day-5 & Day-7 \\
\hline D-dimer $(\mu \mathrm{g} / \mathrm{dl})$ & 1.29 & 2.16 & 0.86 & 0.3 \\
Dosage & $0.4 \mathrm{ml} / 24 \mathrm{~h}$ & $0.4 \mathrm{ml} / 12 \mathrm{~h}$ & $0.4 \mathrm{ml} / 24 \mathrm{~h}$ & Stop \\
\hline
\end{tabular}

\section{CASE 3}

Mr. D was 45 years old, complaining of shortness of breath and cough for 3 days. He had comorbidity of hypertension and diabetic ketoacidosis. The diagnosis of COVID-19 was confirmed by a positive RT-PCR nasopharyngeal swab with chest X-ray bronchopneumonia. The patient had severe clinical symptoms with a d-dimer result $>4.00 \mu \mathrm{g} / \mathrm{dl}$ (>13.3 times the normal value). The patient was given enoxaparin $0.4 \mathrm{ml}$ per 24 hours. The evaluation result of d dimer was $3.36 \mu \mathrm{g} / \mathrm{dl}$ (day 2 of LMWH), then the dose was increased to 0.4 $\mathrm{ml}$ per 12 hours. The evaluation result of d dimer was $2.48 \mu \mathrm{g} / \mathrm{dl}$ (day $10 \mathrm{LMWH}$ ), then the dose was decreased to $0.4 \mathrm{ml}$ per 24 hours. The patient was clinically improved and could be active in mobilization. The evaluation result of d dimer was $1.78 \mu \mathrm{g} / \mathrm{dl}$ (day $13 \mathrm{LMWH}$ ), then enoxaparin was stopped.

Table 3. Case-3 d-dimer Progression After Using Enoxaparin

\begin{tabular}{lcccc}
\hline & \multicolumn{4}{c}{ Day of Enoxaparin Use } \\
& Day-1 & Day-2 & Day-10 & Day-13 \\
\hline D-dimer $(\mu \mathrm{g} / \mathrm{dl})$ & $>4.00$ & 3.36 & 2.48 & 1.78 \\
Dosage & $0.4 \mathrm{ml} / 24 \mathrm{~h}$ & $0.4 \mathrm{ml} / 12 \mathrm{~h}$ & $0.4 \mathrm{mi} / 24 \mathrm{~h}$ & Stop \\
\hline
\end{tabular}

\section{CASE 4}

Mr. E was 77 years old, complaining of shortness of breath for one day. He had comorbidity of chronic heart failure NYHA 3, hyperglycemia, and acute kidney injury. The diagnosis of COVID-19 was confirmed by a positive RT-PCR nasopharyngeal swab with chest X-ray pulmonary edema mixed pneumonia and cardiomegaly. Creatinine serum was $2.61 \mathrm{mg} / \mathrm{dL}$ then improved to $1.64 \mathrm{mg} / \mathrm{dL}$. The patient had severe clinical symptoms with a d-dimer result of $>4.00 \mu \mathrm{g} / \mathrm{dl}$ ( $>13.3$ times the normal value). The patient was given enoxaparin $0.6 \mathrm{ml}$ per 24 hours. The evaluation result of $\mathrm{d}$ dimer was still $>4.00 \mu \mathrm{g} / \mathrm{dl}$ (day 5 of LMWH), and enoxaparin was given with the same dose. The evaluation result of d-dimer was $2.89 \mu \mathrm{g} / \mathrm{dl}$ (day $10 \mathrm{LMWH}$ ), and the dose of enoxaparin was $0.4 \mathrm{ml}$ per 12 hours. The last evaluation result of d-dimer was $1.76 \mu \mathrm{g} / \mathrm{dl}$ (day $12 \mathrm{LMWH}$ ). The clinical and radiological evaluation results improved; there was no bleeding during the administration of LMWH. The patient went home with clinical improvement.

Table 4. Case-4 d-dimer Progression After Using Enoxaparin 


\begin{tabular}{lcccc}
\hline & \multicolumn{4}{c}{ Day of Enoxaparin Use } \\
& Day-1 & Day-5 & Day-10 & Day-12 \\
\hline D-dimer $(\mu \mathrm{g} / \mathrm{dl})$ & $>4.00$ & $>4.00$ & 2.89 & 1.76 \\
Dosage & $0.6 \mathrm{ml} / 24 \mathrm{~h}$ & $0.6 \mathrm{ml} / 24 \mathrm{~h}$ & $0.4 \mathrm{ml} / 12 \mathrm{~h}$ & Stop \\
\hline
\end{tabular}

\section{CASE 5}

Mrs. F was 60 years old, complaining of shortness of breath and cough. She had chronic kidney disease stage $V$ comorbidity, anemia, hypertension, and diabetes mellitus. The diagnosis of COVID-19 was confirmed by a positive RT-PCR nasopharyngeal swab with chest X-ray pulmonary edema mixed pneumonia and cardiomegaly. The patient had moderate clinical symptoms with a d-dimer result of $1.39 \mathrm{\mu g} / \mathrm{dl}$ ( 4.6 times the normal value) and was given unfractionated heparin (UFH) 5000 IU per 12 hours. The evaluation result of d-dimer was $1.34 \mu \mathrm{g} / \mathrm{dl}$ (day 4 of UFH), then UFH was given with the same dose. The last evaluation result of the d-dimer was $0.97 \mu \mathrm{g} / \mathrm{dl}$ (day 6 UFH). The clinical and radiological evaluation results improved; there was no bleeding during the administration of UFH. The patient went home with clinical improvement.

Table 5. Case-5 d-dimer Progression After Using Enoxaparin

\begin{tabular}{lccc}
\hline & \multicolumn{3}{c}{ Day of Unfractionated Heparin (UFH) Use Subcutaneously } \\
& Day-1 & Day-4 & Day-6 \\
\hline D-dimer $(\mu \mathrm{g} / \mathrm{dl})$ & 1.39 & 1.34 & 0.97 \\
Dosage & $5000 \mathrm{IU} / 12 \mathrm{~h}$ & $5000 \mathrm{IU} / 12 \mathrm{~h}$ & stop \\
\hline
\end{tabular}

\section{DISCUSSION}

Coagulopathy is a term that refers to any homeostasis problem that results in excessive bleeding or clotting and is commonly known as a clot formation problem. ${ }^{8}$ The International Society of Thrombosis and Homeostasis (ISTH) has established and validated a sepsis-induced coagulopathy (SIC) score in addition to diagnostic criteria for overt DIC. ${ }^{9-11}$ Chinese COVID-19 outbreak reports already used both ISTH definitions. ${ }^{12,13}$

Coagulopathy is common in SARS-CoV-2 infection and is marked by an increase of d-dimer. ${ }^{14}$ Guan et al. reported their large studies with 560 cases in which 260 cases have increased d-dimer (46.4\%). Their studies found that conditions happened $60 \%$ in ICU patients and $43 \%$ in non-severe patients. ${ }^{5}$ Increased Ddimer levels are possibly due to inflammation caused by COVID-19 and subsequent activation of coagulation, as elevated levels have been related to several conditions other than thromboembolism, with infection being the main cause. ${ }^{15-17}$

In these cases, the researchers found that all patients have high d-dimer above the normal levels. Zhou et al. ${ }^{4}$ found that poor prognosis and increased mortality were related to elevated d-dimer. Zhang et al. ${ }^{18}$ examined 343 cases and found that d-dimer levels over $2.0 \mathrm{mg} / \mathrm{L}$ could predict mortality with a sensitivity of $92.3 \%$ and a specificity of $83.3 \%$. Consequently, based on the disease's progression, maximizing a particular treatment may be the best choice. ${ }^{19,20}$ In mild to serious COVID-19 patients, interim advice from the International Society on Thrombosis and Haemostasis (ISTH) suggests prophylactic low-molecular-weight heparin $(\mathrm{LMWH}) .^{21,22}$

Low-molecular-weight heparins (LMWHs) are a new class of anticoagulants made from unfractionated heparin (UFH) and depolymerized chemically or enzymatically to yield fragments around onethird the size of heparin. ${ }^{23}$ They have some benefits over UFH, which has led to increased use for a range of thromboembolic indications. ${ }^{24} \mathrm{LMWHs}$ activate antithrombin (AT) like UFH to create their key anticoagulant effect. ${ }^{23}$ Anticoagulants are low-molecular-weight heparins (LMWHs), such as dalteparin and enoxaparin. These medications are used to prevent venous thromboembolic disease (VTE) during an acute or elective hospital stay, to treat deep vein thromboses (DVT), pulmonary embolism (PE), and unstable angina, and are now prescribed in mild to serious COVID-19 with symptoms of coagulopathy. ${ }^{22,23,25}$ The researchers used enoxaparin with prophylaxis dose to treat the patients in this case report, and unfractionated heparin was used in one case.

If there is no contraindication, such as platelet less than $25 \times 10^{9} / \mathrm{L}$, ISTH suggested giving a prophylactic dosage of LMWH to all COVID-19 who needed to hospitalize. ${ }^{21}$ In another systematic review and meta-analysis, LMWH was safe as UFH. As a result, their efficacy is also debatable, owing to the possibility of bioaccumulation in patients with renal problems. ${ }^{26}$ Our Case- 5 showed the use of unfractionated heparin (UFH) in chronic kidney disease patients, then gave good results that d-dimer level response became normal level without any complication happened.

Furthermore, Ning Tang et al. recently investigated the advantage of LMWH use in sepsis-induced coagulopathy and discovered that LMWH tends to be correlated with an improved prognosis in terms of 
mortality ( $40.0 \%$ vs. $64.2 \%, p=0.029$ ). Those with $D$-dimer $>6$-fold of the average upper limit had a comparable gain $(32.8 \%$ vs. $52.4 \%, P=.017) .^{13}$

Since the evidence indicates that genetic risk factors and VTE prevalence differ significantly among ethnic groups, and since the incidence of VTE in Asian populations is low, 27,28 a higher dose of LMWH may be recommended in the non-Asian population with severe COVID-19. On the other hand, anticoagulant treatment for sepsis-associated DIC is still debatable. ${ }^{29,30}$ The ISTH created the SIC guidelines to direct anticoagulant therapy as platelet counts decrease and prothrombin time prolongation is connected to increased mortality, and hypofibrinogenemia is rare in sepsis. The utility of this simple score has already been shown. ${ }^{31}$

In case 2 and 5, LMWH was given for one week or less, and the d-dimer profile showed improvement, while in case 1,3 and 4, LMWH was given for more than one week. Case 3 and 4 had incoming d-dimer levels $>4 \mathrm{\mu g} / \mathrm{dl}$ with severe COVID-19. Improvements in d-dimer levels were related to the improvement in the condition of COVID-19 itself and the improvement of inflammation in COVID-19 patients. Severe COVID-19 requires a longer time to repair inflammation than moderate COVID-19. ${ }^{32}$

The three most serious drug-related complications associated with heparin and LMWH treatment are thrombocytopenia, bleeding, and osteopenia. ${ }^{33}$ Heparin-induced thrombocytopenia (HIT) affects $3 \%$ to $5 \%$ of patients administered unfractionated heparin intravenously, compared to 0.5 percent of patients receiving subcutaneous $\mathrm{LMWH}$, catheter flushes, or even small levels of heparin that leach from coated catheters. Heparin-induced Thrombocytopenia with Thrombosis (HITT) is a severe prothrombotic diathesis that can result in venous or arterial thromboembolism in $50 \%$ of cases. Under timely and successful care, approximately $20 \%$ of patients will have their limbs amputated, up to $30 \%$ will die, and survivors will have residual deficits that can lead to myocardial infarctions, strokes, and pulmonary emboli. Heparin should be stopped as soon as platelet counts drop dramatically (usually 50\% of baseline), and lepirudin or argatroban (direct thrombin inhibitors) should be started if anticoagulation is needed. 34,35 Five patients in this report had normal thrombocyte levels before and after using enoxaparin and UFH.

Furthermore, bleeding is the most common side effect of anticoagulant therapy, and LMWH has a lower risk than UFH. Since LMWH is completely excreted by the kidneys, renal activities and creatinine clearance $(\mathrm{CrCl})$ should be controlled in elderly and frail patients rather than only serum creatinine. For patients in this indication group, the lowest $\mathrm{CrCl}$ ratio is likely to be various $\mathrm{LMWHs}$, although a reasonable threshold is likely to be $30 \mathrm{~mL} / \mathrm{min}$. The lower $\mathrm{CrCl}$ ratio can cause hemorrhaging and should not be used. 33 Intermittent intravenous (IV) heparin causes more major bleeding than continuous IV heparin; however, continuous IV heparin and subcutaneous heparin cause almost the same amount of bleeding. ${ }^{33}$ In this report, all of the patient's hemoglobin was still at the same level after using enoxaparin or UFH. There were not any symptoms associated with bleeding. Protamine can be used to counteract the effects of heparin when bleeding happens during UFH treatment.

On the other hand, protamine tends to neutralize just about $60 \%$ of LMWH's anti-factor Xa activity. ${ }^{33}$ In Case4, the researchers calculated the patient's $\mathrm{CrCl}$ (Cockcroft-Gault Equation), which was approximately 20 $\mathrm{mL} / \mathrm{min}$. Close observation of this patient found no complications such as bleeding.

Osteopenia and osteoporosis associated with heparin are linked to long-term treatment (usually more than one month). They are uncommon but often occur during breastfeeding and the postpartum phase, leading to fractures spontaneously. In this report, all cases were only short-term therapy; thus, this complication did not happen. Balance disruption of osteoclasts and osteoblasts, abnormal collagen activation, and vitamin D synthesis disruptions can all induce heparin-associated osteopenia. ${ }^{33}$

\section{CONCLUSION}

The conclusion is that anticoagulants had been widely recommended to be given to COVID-19 patients, especially with moderate to severe degrees, to reduce mortality from coagulopathy. In this report, either patient who used enoxaparin LMWH or heparin UFH responded well; all d-dimer levels gradually became normal and experienced clinical improvement without any complication.

\section{CONFLICT OF INTEREST}

There are no conflicts of interest declared by either of the contributors.

\section{REFERENCES}


1. Zhu H, Wei L, and Niu P. The novel coronavirus outbreak in Wuhan, China. Glob Health Res Policy. 2020 Dec;5(1):6. https://doi.org/10.1186/s41256-020-00135-6

2. Emami A, Javanmardi F, Pirbonyeh N, and Akbari A. Prevalence of Underlying Diseases in Hospitalized Patients with COVID-19: a Systematic Review and Meta-Analysis. Arch Acad Emerg Med. 2020; 8(1): e35: 1 14

3. Yi Y, Lagniton PNP, Ye S, and Li E, Xu R-H. COVID-19: what has been learned and to be learned about the novel coronavirus disease. Int J Biol Sci. 2020;16(10):1753-66. https://doi.org/10.7150/ijbs.45134

4. Zhou F, Yu T, Du R, Fan G, Liu Y, Liu Z, et al. Clinical course and risk factors for mortality of adult inpatients with COVID-19 in Wuhan, China: a retrospective cohort study. The Lancet. 2020;395(10229):1054-62. https://doi.org/10.1016/S0140-6736(20)30566-3

5. Guan W, Ni Z, Hu Y, Liang W, Ou C, He J, et al. Clinical Characteristics of Coronavirus Disease 2019 in China. New England Journal of Medicine. 2020;382(18):1708-20. https://doi.org/10.1056/NEJMoa2002032

6. Klok FA, Kruip MJHA, Van der Meer NJM, Arbous MS, Gommers DAMPJ, Kant KM, et al. Incidence of thrombotic complications in critically ill ICU patients with COVID-19. Thrombosis Research. 2020;191:145-7. https://doi.org/10.1016/j.thromres.2020.04.013

7. Llitjos JF, Leclerc M, Chochois C, Monsallier JM, Ramakers M, Auvray M, et al. High incidence of venous thromboembolic events in anticoagulated severe COVID-19 patients. Journal of Thrombosis and Haemostasis. 2020;18(7):1743-6. https://doi.org/10.1111/jth.14869

8. Vanderwerf JD, and Kumar MA. Management of neurologic complications of coagulopathies. 1st ed. Vol. 141, Handbook of Clinical Neurology. Elsevier B.V.; 2017. 743-764 p.

9. Suzuki K, Wada H, Imai H, Iba T, Thachil J, and Toh CH. A re-evaluation of the D-dimer cut-off value for making a diagnosis according to the ISTH overt-DIC diagnostic criteria: communication from the SSC of the ISTH. Journal of Thrombosis and Haemostasis. 2018;16(7):1442-4. https://doi.org/10.1111/jth.14134

10. Iba T, Levy JH, Warkentin TE, Thachil J, van der Poll T, and Levi M. Diagnosis and management of sepsisinduced coagulopathy and disseminated intravascular coagulation. Journal of Thrombosis and Haemostasis. 2019;17(11):1989-94. https://doi.org/10.1111/jth.14578

11. Toh CH, and Hoots WK. The scoring system of the Scientific and Standardisation Committee on Disseminated Intravascular Coagulation of the International Society on Thrombosis and Haemostasis: A 5 year overview. Journal of Thrombosis and Haemostasis. 2007;5(3):604-6. https://doi.org/10.1111/j.1538. 7836.2007.02313.x

12. Tang N, Li D, Wang X, and Sun Z. Abnormal coagulation parameters are associated with poor prognosis in patients with novel coronavirus pneumonia. Journal of Thrombosis and Haemostasis. 2020;18(4):844-7. https://doi.org/10.1111/ith.14768

13. Tang N, Bai H, Chen X, Gong J, Li D, and Sun Z. Anticoagulant treatment is associated with decreased mortality in severe coronavirus disease 2019 patients with coagulopathy. Journal of Thrombosis and Haemostasis. 2020;18(5):1094-9. https://doi.org/10.1111/jth.14817

14. Iba T, Levy JH, Levi M, Connors JM, and Thachil J. Coagulopathy of Coronavirus Disease 2019. Critical Care Medicine. 2020;48(9):1358-64. https://doi.org/10.1097/CCM.0000000000004458

15. Iba T, Levy JH, Wada H, Thachil J, Warkentin TE, and Levi M. Differential diagnoses for sepsis-induced disseminated intravascular coagulation: communication from the SSC of the ISTH. Journal of Thrombosis and Haemostasis. 2019 Feb 7;17(2):415-9. https://doi.org/10.1111/jth.14354

16. Levi M, and Scully M. How I treat disseminated intravascular coagulation. Blood. 2018;131(8):845-54. https://doi.org/10.1182/blood-2017-10-804096

17. Lippi G, Bonfanti L, Saccenti C, and Cervellin G. Causes of elevated D-dimer in patients admitted to a large urban emergency department. European Journal of Internal Medicine. 2014;25(1):45-8. https://doi.org/10.1016/j.ejim.2013.07.012

18. Zhang L, Yan X, Fan Q, Liu H, Liu X, Liu Z, et al. D-dimer levels on admission to predict in-hospital mortality in patients with Covid-19. Journal of Thrombosis and Haemostasis. 2020;18(6):1324-9. https://doi.org/10.1111/ith.14859

19. Iba T, Levy JH, Thachil J, Wada H, and Levi M. The progression from coagulopathy to disseminated intravascular coagulation in representative underlying diseases. Thrombosis Research. 2019;179(January):11-4. https://doi.org/10.1016/j.thromres.2019.04.030

20. Delabranche X, Helms J, and Meziani F. Immunohaemostasis: a new view on haemostasis during sepsis. Annals of Intensive Care. 2017;7(1):1-14. https://doi.org/10.1186/s13613-017-0339-5

21. Thachil J, Tang N, Gando S, Falanga A, Cattaneo M, Levi M, et al. ISTH interim guidance on recognition and management of coagulopathy in COVID-19. Journal of Thrombosis and Haemostasis. 2020;18(5):1023-6. https://doi.org/10.1111/ith.14810 


\section{mutiara medika \\ Jurnal Kedokteran dan Kesehatan}

22. Godino C, Scotti A, Maugeri N, Mancini N, Fominskiy E, Margonato A, et al. Antithrombotic therapy in patients with COVID-19? Rationale and Evidence- Int. J. Cardiol. 324: 261-266. https://doi.org/10.1016/j.ijcard.2020.09.064

23. Hirsh J. Low-Molecular-Weight Heparin: A Review of the Results of Recent Studies of the Treatment of Venous Thromboembolism and Unstable Angina. Circulation. 1998;13:98(15):1575-82. https://doi.org/10.1161/01.cir.98.15.1575

24. Weitz J. Low-Molecular-Weight Heparin. The New England Journal of Medicine. 1997;688-98.

25. Dong K, Song Y, Li X, Ding J, Gao Z, Lu D, et al. Pentasaccharides for the prevention of venous thromboembolism. Cochrane Database of Systematic Reviews. 2016;2016(10). https://doi.org/10.1002/14651858.CD005134.pub3

26. Lazrak HH, René É, Elftouh N, Leblanc M, and Lafrance JP. Safety of low-molecular-weight heparin compared to unfractionated heparin in hemodialysis: a systematic review and meta-analysis. BMC Nephrology. 2017;18(1):1-12. https://doi.org/10.1186/s12882-017-0596-4

27. Stein PD, Kayali F, Olson RE, and Milford CE. Pulmonary thromboembolism in Asians/Pacific Islanders in the United States: Analysis of data from the National Hospital Discharge Survey and the United States Bureau of the Census. American Journal of Medicine. 2004;116(7):435-42. https://doi.org/10.1016/j.amjmed.2003.11.020

28. Zakai NA, and Mcclure LA. Racial differences in venous thromboembolism. Journal of Thrombosis and Haemostasis. 2011;9(10):1877-82. https://doi.org/10.1111/j.1538-7836.2011.04443.x

29. Aikawa N, Shimazaki S, Yamamoto Y, Saito H, Maruyama I, Ohno R, et al. Thrombomodulin alfa in the treatment of infectious patients complicated by disseminated intravascular coagulation: Subanalysis from the phase 3 trial. Shock. 2011;35(4):349-54. https://doi.org/10.1097/SHK.0b013e318204c019

30. Liu XL, Wang XZ, Liu XX, Hao D, Jaladat Y, Lu F, et al. Low-dose heparin as treatment for early disseminated intravascular coagulation during sepsis: A prospective clinical study. Experimental and Therapeutic Medicine. 2014;7(3):604-8. https://doi.org/10.3892/etm.2013.1466

31. Iba T, Di Nisio M, Levy JH, Kitamura N, and Thachil J. New criteria for sepsis-induced coagulopathy (SIC) following the revised sepsis definition: A retrospective analysis of a nationwide survey. BMJ Open. 2017;7(9):1-7. http://dx.doi.org/10.1136/bmjopen-2017-017046

32. Yu B, Li X, Chen J, Ouyang M, Zhang H, Zhao X, et al. Evaluation of variation in D-dimer levels among COVID-19 and bacterial pneumonia: a retrospective analysis. J Thromb Thrombolysis. 2020 Oct;50(3):548-57. https://doi.org/10.1007/s11239-020-02171-y

33. Krishnamurthy M, and Freedman ML. Complications of Anticoagulation with Heparin. Ethics Journal of the American Medical Association. 2005:7(4). https://doi.org/10.1001/virtualmentor.2005.7.4.cprl1-0504

34. Warkentin TE, and Greinacher A. Heparin-induced thrombocytopenia: Recognition, treatment, and prevention - The Seventh ACCP Conference on Antithrombotic and Thrombolytic Therapy. Chest. 2004;126(3 SUPPL.):311S-337S. https://doi.org/10.1378/chest.126.3 suppl.311S

35. Rice L. Heparin-induced thrombocytopenia: myths and misconceptions (that will cause trouble for you and your patient). Archives of internal medicine. 2004;164(18):1961-4. https://doi.org/10.1001/archinte.164.18.1961 